\title{
Land Use and Environmental Zoning of Mixed Ombrophilous Forests for Sustainable Use (Irati National Forest, Brazil Southern Region)
}

\author{
Carlos Alberto da Silva Mazza1; Maria Cristina Medeiros Mazza1; Dayana Almeida1; José \\ Eduardo dos Santos²; Angela Terumi Fushita ${ }^{2 *}$. \\ ${ }^{1}$ Universidade Federal de São Carlos, Environmental Analysis and Planning Laboratory/ PPGERN, São Carlos, São \\ Paulo, Brasil; ${ }^{2}$ Universidade Federal de São Carlos, Departamento de Hidrologia, São Carlos, São Paulo, Brasil;
}

\begin{abstract}
An environmental zoning proposal due to the demand to develop strategies to ensure biodiversity scenarios for the remaining mixed ombrophilous forests was carried out for the Irati National Forest, a legally protected area for sustainable use located in southern Brazil. To identify land use and cover, Ikonos PSM images dated from December 2004, based on the interpretation of visual character and vectorization of orbital data were used. Qualitative and quantitative classifications identified six types of land and cover use: native forest, forestry, capoeira grass, wetland, araucaria plantation, and anthropic. The native forest relative to the mixed ombrophilous forest was the prevailing type of land cover. The environmental zoning proposal defined seven zones of use, some that involved several potentially harmful activities to the biodiversity of the Irati National Forest. The environmental zone proposal, based on ecosystem conservation, outlined specific factors that enhanced ecosystem and community viability, supporting the design and evaluation of the management plan of the Irati National Forest.
\end{abstract}

Key-words: environmental zoning; environmental characterization; biodiversity conservation; legally protected area; geographic information system

*Authors for correspondence: angela_fushita@yahoo.com.br 


\section{INTRODUCTION}

Natural ecosystems have been increasingly replaced by cultural ecosystems in the last two decades, with agriculture as the main process of forest conversion in the global environment (Matson et al. 1997; Helmut and Lambin 2002; Lambin and Meyfroidt 2011; Laurance et al. 2014). In the humid tropics region natural ecosystems is widely restricted to the hot-spot areas, which have shown considerably alarming rates of change (Achard et al. 2002; Costa et al. 2007). These changes have resulted in an alteration in biodiversity and ecosystem processes, modification in ecosystem resilience with respect to environmental changes (Chapin et al. 2000), and maintenance of the provision of ecosystem services to human well-being (Millennium Ecosystem Assessment 2006).

However, the domestication of landscapes and ecosystems has provided net benefits to society, especially those related to the maximization of productivity (Kareiva et al. 2007). The technology and knowledge currently available can greatly reduce the human impact on ecosystems and biodiversity loss. Nevertheless, the use of this potential will continue to be minimal while the ecosystem services continue to be perceived as free, unlimited, and beneficial (Millennium Ecosystem Assessment 2006).

The recent release of forest cover change estimates for Brazil provided an opportunity to assess variable forest transitions and explore implications in terms of promoting sustainability. The trajectory of forest loss in Brazil from 2000 to 2010 (236,600 $\mathrm{km}^{2}$ ) was mostly due to the expansion of agricultural activities, representing $65 \%$ of total deforestation in the period. In the corresponding period, the expansion of pasture areas accounted for the other $35 \%$ of deforestation, totaling 127,200 $\mathrm{km}^{2}$ of Amazon or Atlantic Forest areas. Particularly, between 2010 and 2012, there was an increase in the processes of land use and cover in Brazil, where changes in the landscape reached $3.5 \%$ of the country. The expansion of the agricultural frontier has intensified, with the deforestation of $77,520 \mathrm{~km}^{2}(68 \%$ of total deforestation), while the expansion of planted pastures accounted for $28 \%$ of deforestation, or $32,120 \mathrm{~km}^{2}$ (IDS 2015).

The mixed ombrophilous forest (Araucaria Forest) component of the Atlantic Forest biome in southern
Brazil is considered one of the most endangered forests, mainly due to anthropogenic pressure drivers in their structure and composition related to the extraction and replacement of primary land cover. Remaining area of this typical phytophysiognomic formation in southern Brazil, in Paraná state, is currently reduced to fragments in different successional stages, distributed mainly in the mid-south region, located on private properties, in areas of surface relief, margins of rivers or in legally protected areas (PROBIO 2001; Castella and Britez 2004). It is important to highlight that, about 15 years ago, primary forests accounted for $0.7 \%$ of the total area of occurrence of Araucaria Forest in Paraná state. This area was not identified in recent studies, which only referenced $0.8 \%$ in an advanced successional stage (PROBIO 2001). Authenticating the gradual decrease occupied by the mixed ombrophilous forest, in 1930, 64.1\% comprised original cover, in 1937 (58.7\%), 1950 (39.7\%), 1965 (23.9\%), 1980 (11.9\%), and 1990 (5.2\%) (Gubert 1988).

The creation of legally protected areas is the main strategy for biodiversity conservation, minimizing the risk of species and habitat loss, and maximizing the ecosystem integrity and representativity of ecological communities and their constituent species (United Nations 2001). The management of legally protected areas requires environmental zoning that aims to provide the means and conditions to which its functions are fulfilled in effective and balanced means (BRASIL 2000; 2002). This study carried out an environmental zoning proposal of the Irati National Forest, which was in search of a technical tool to develop its management plan.

\section{MATERIAL AND METHODS}

\section{Study Area}

The Irati National Forest, according to National System of Conservation Units (BRASIL 2000), is a legally protected area of sustainable use comprising the mixed ombrophilous forest domain, known as Araucaria Forest, which is regarded as one of the most important phytophysiognomies in southern Brazil (Veloso and Goes-Filho 1982). The Irati National Forest was created based on Act No. 559 on October 25, 1968. The forest is located on the Second Plateau of Paraná, Colonial Microregion of Irati (Fig. 1), limited by Fernandes Pinheiro, 
Teixeira Soares, Imbituva and Irati municipalities in the valley of the Imbituva River, which, together with the Antas River, correspond to the main limits of the protected area (Mazza et al. 2005). The climate of the region is Cfb type - Mesothermal Humid Subtropical, characterized by cool summers, frequent and severe frosts and no dry season (Caviglione et al., 2000). The surrounding area of the Irati National Forest is known for its phytophysionomically unique features, represented by floodplains and natural fields of mosaics associated with Araucaria Forest formations.

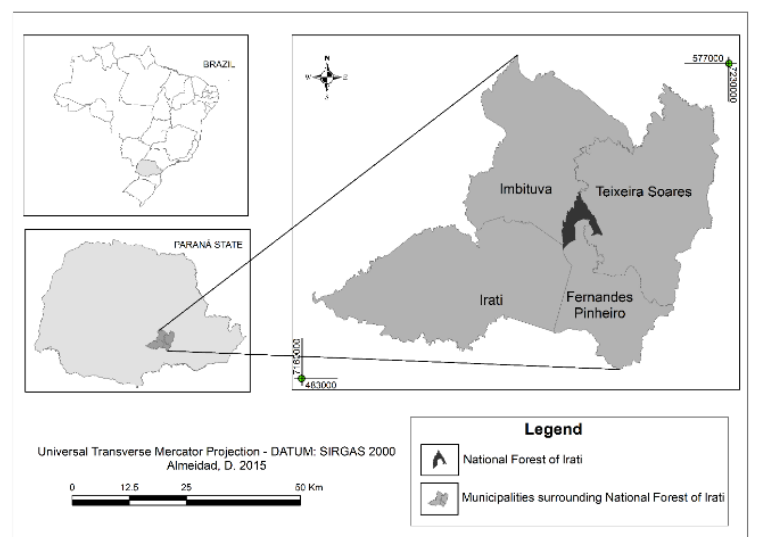

Figure 1: The location of the Irati National Forest limited by Fernandes Pinheiro, Teixeira Soares, Imbituva and Irati municipalities (state of Parana, Brazil).

The environmental characterization of the Irati National Forest was based on the digital elevation model obtained through the "Shuttle Radar Topography Mission" project (USGS 2005). From the digital elevation model, clinography and hypsometry maps were generated with ArcView, version 9 and Spring, version 4.1.

The Irati National Forest is comprised of topographical features ranging from rugged surfaces to strongly rugged surfaces (MINEROPAR 2001). The altitude ranges from 788-899 m, with $111 \mathrm{~m}$ of amplitude and declivity ranging from $0.01 \%$ to $87 \%$. Approximately $82 \%$ of the total area of the Irati National Forest is seated on a slope from $0-10 \%$. Slope values greater than $8 \%$ show a moderate to strongly rugged surface. Approximately $82 \%$ of the total area of the Irati National Forest is above $8 \%$, requiring care in conservation (EMBRAPA 1995).

The soil map available at a scale of 1:300,000 was adapted from the Brazilian Agricultural Research Corporation - National Research Center for Soils.
The soil types of the Irati National Forest of Irati were categorized into three distinct groups. The Dystrophic Red Oxisols group is located in the western portion of the conservation area, occupying $2,345.05$ ha, which represents $64.81 \%$ of the total area of the Irati National Forest. The Dystrophic Haplic Cambisols occupy an area of 921.04 ha, which corresponds to $25.46 \%$ of the total area of the Irati National Forest, located in the wetland areas along the Imbituva River. Finally, the Dystrophic Red-Yellow Ultisols occupy 352.12 ha, about $9.73 \%$ of the total area, located in the southeastern region, and a small area in the eastern region (Mazza et al. 2005).

\section{Methodological Procedures}

This work is part of the project "Conservation and Sustainable Use of Non-Timber Forest Remnants of Araucaria Forest - CONSERVABIO $(\mathrm{CNPq}$ 070/2009 PGAES), proposed to form a multidisciplinary and multi-institutional organizational base and research network (CONSERVABIO Network). This project is related to conservation, sustainable use and management of National Forests, considering the surrounding's family farmers and traditional communities. The CONSERVABIO Network was developed for National Forests located in the mixed ombrophilous forests areas in the South region of Brazil: Irati National Forest, Paraná state, Três Barras National Forest, Santa Catarina state, and Passo Fundo National Forest, Rio Grande do Sul state, and their surroundings in territorial scope. The project was coordinated by Embrapa Forests (Paraná state) and with the participation of several educational and research institutions (ICMBio, UFSC, UFSCar, URI / RS, UNICENTRO, and also by nongovernmental organizations (AS-PTA, CETAP, EPAGRI, EMATER, Farmers' Organizations, as well as a large number of public institutions and civil society with local operations in these areas where the project was developed.

The time and field effort devoted to provide substantial landscape structural data concerning to Irati National Forest, covered the period from 2002 to 2006, with 04 field testing per year, considering a period of 01 week for each field testing.

The boundaries of the study area were rectified and interpreted based on the scanned forest map of the Irati National Forest (FUPEF 1986), and overlaid on the Ikonos imagery of the study area. The land use and cover classification (IBGE 2013), inside 
and around of the Irati National Forest, were carried out annually considering the visual character of the Ikonos PSM image dated December 2004, by collecting at least 20 samples polygons for each type of land use and cover. This resulted in the assignment of a "pixel" for each category of land use and cover, creating vector polygons through screen digitalization with ArcView, version 9 and Spring, version 4.1.The recognition of spectral signatures was based on polygons sampled overlapping on the Ikonos image, and subsequent return to field testing for ground truthing.

The Irati National Forest environmental zoning proposal was based on the Elaboration of Management Plan for National Forests (IBAMA 2003). The management zone proposal was based on BRASIL (2002), elaborate with adaptations according to specific objectives and to ensure guidelines compliance with pre-defined goals for a National Forest.

The buffer zone of the Irati National Forest (BRASIL 2002) was established as $1 \mathrm{~km}$ wide, identifying types of land use and cover that should be subject to specific rules and restrictions in order to minimize negative impacts on the National Forest. The environmental characterization related to surrounding conditions of Irati National Forest (land use, hydrology, soils, road net, hypsometry, clinography, and limit), and a strengths and weaknesses analysis as well as legal issues were also considered.

Since 2011, the authors have been interacting with managers and researchers National Forests of Irati (Paraná state), Três Barras (Santa Catarina state), and Passo Fundo (Rio Grande do Sul state, by continuing research project (Project Code: 06.10.06.001.00.00, Project Title: Network for Biodiversity Conservation and Valuation of Araucaria Forest Products - CONSERVABIO II), through effective participation in their Management Councils and field visits. All knowledge acquired with these interactions and research effort, were considered and included in the zoning guidelines and criteria proposals.

\section{RESULTS AND DISCUSSION}

\section{Land Use and Cover}

The total area of the Irati National Forest, estimated by interpretation and limit rectification, is 3,618 ha. Nearly $73.7 \%$ of this area belongs to Pinheiro Fernandes, and $26.3 \%$ to Teixeira Soares municipalities.

Eight types of land use and cover were identified: native forest, forestry, capoeira grass, wetland, araucaria plantation, and anthropic (Fig. 2).

The native forest relative to the mixed ombrophilous forest occupies $44.6 \%$ of the total area and comprises the prevailing type of land cover of the Irati National Forest. At a regional scale, the mixed ombrophilous forest formation reflects the intense fragmentation existing in the State of Paraná. The Araucaria angustifolia plantation occupies nearly of $12.8 \%$ of the Irati National Forest's total area and is located in its western and east-central region, near settlements. This plantation began in 1946 and currently comprises a dense understory formed by natural forest regeneration of the original matrix. The Pinus spp and Eucalyptus spp forestry occupies $24.2 \%$ of the total area of the Irati National Forest and is located in the east-west and central regions. These species were previously introduced to promote exotic species cultivation for wood production (Fig. 2).

Capoeira grass occupies $5.0 \%$ of the Irati National Forest (Fig. 2) and is associated with different successional stages of secondary vegetation composed of sparsely distributed herbaceous and shrub vegetation (Hohnwald et al. 2006; Wandelli and Fearnside 2015). This secondary vegetation is usually related with Imbituva and Antas Rivers' wetlands. The occurrence of this cover use is also associated with fallow vegetation management areas, commonly used by farmers, which leave the land unsown for a period to restore its fertility without any kind of production, being colonized only by pioneer species. 


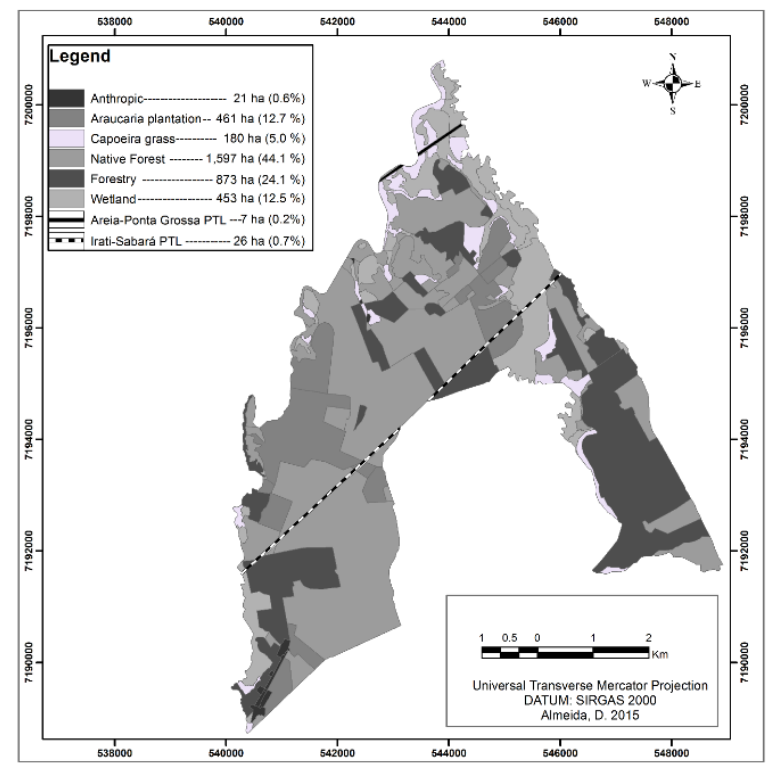

Figure 2: Land use and cover types of the Irati National Forest, Paraná state, Brazil. Areia-Ponta Grossa Power Transmission Line (PTL). Irati-Sabará Power Transmission Line (PTL).

The wetland occupied $12.8 \%$ of the total area of the Irati National Forest (Fig. 2) and was mainly associated with Imbituva and Antas Rivers and their effluents, which were sourced from the protected area.

The Araucaria angustifolia plantations occupied $12.8 \%$ of the area of the national forest (Fig. 2) and were located in the western and east-central regions, generally near adjacent settlements. These plantations were established in 1946, during the creation of Enrique Manoel da Silva Forest Park; they composed a dense understory formed by the natural regeneration of the original matrix.

The anthropic cover use occupied $0.6 \%$ of the total area of the Irati National Forest (Fig. 2) and included the road net, Power Transmission Lines (PTLs), and infrastructure. The infrastructure cover use supported the administrative activities and was located in the southwest region, next the entrance to the protected area. The infrastructure components were composed of administration buildings, staff housing, a garage, nursery, museum, church, school, club, guest house, shed, warehouse and guardhouse. The road net allowed access to the protected area.

Two PTLs crossed the Irati National Forest from east to west (Fig. 2). The Irati-Sabara PTL was managed by the Electrical Energy Company of Paraná and operated at $138 \mathrm{kV}$. This transmission line extended about 7,900 m (26 ha) across wetlands, native forests, Araucaria cultivations, and forestry. The Areia-Ponta PTL Grossa was managed by the Electric Central Corporation (ELETROSUL) and operated at $230 \mathrm{kV}$. This PTL extended about $1,500 \mathrm{~m}$ (7 ha) and was fully allocated in wetland and capoeira grass areas.

\section{Environmental Zoning}

The environmental zoning aimed to ensure the protection of the remaining fragments of natural vegetation and schedule activities of sustainable use of biodiversity and scientific research as well as educational and environmental interpretation programs.

The environmental zoning proposal for the Irati National Forest (Fig. 3) prioritized the protection of the remaining fragments of natural vegetation and scheduled activities of sustainable use of biodiversity conservation and scientific research, as well as educational and environmental interpretation programs. This proposal included eight zones with different management categories, presented a gradient of environmental complexity considering both natural and modified areas with high and low biodiversity, respectively. The reported proposal described the structure of the eight zoning areas required as a prior condition to ensure the objectives set for this legally protected area category.

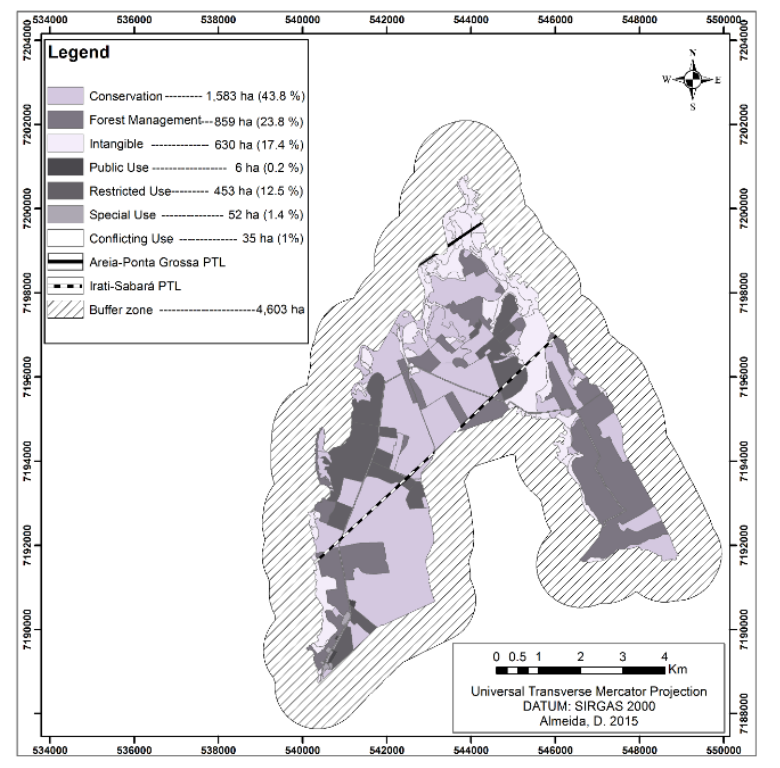

Figure 3: Environmental zoning proposal of the Irati National Forest (Paraná state, Brazil). Power Transmission Lines (PTL). 
Intangible Zone: This zone covers an area of 630 ha, which corresponds to $17.4 \%$ of the total area of the Irati National Forest, and includes and Antas and Imbituva River wetlands, and sparsely distributed herbaceous vegetation and capoeira grass (Fig. 3). The aim of the area is to maintain the nature primitiveness with low or no human interference. This area is intended to protect ecosystems and genetic resources, and for environmental monitoring. Dystrophic Haplic Cambisols and Dystrophic Red Oxisols occur here, and slope values range from 0.10 to $36.65 \%$.

Zoning criteria: High environmental variability, species diversity, environmental susceptibility, and potential for awareness.

Administration Guidelines: The public is denied access to this zone, and scientific research is limited to biodiversity maintenance and management. The zone has ecological significance and strategic importance in terms of the life cycles of the associated species. The wetlands play a key role in habitats with high values of primary productivity available for aquatic and terrestrial food webs. They also act as areas of sedimentation, water purification and decomposition and/or sequestration of toxic products. The reduction and/or degradation of wetland areas by hunting and overfishing activities may compromise the ecosystemic functions related to flooding, and may increase toxic products due to the decreased degradation ability of water resources (Howard and Thompson 1985).

Conservation Zone: This zone covers an area of 1,583 ha, which corresponds to $43.8 \%$ of the total area of the Irati National Forest. The zone is intended for the permanent preservation of environmental habitats with minimal human interventions, and the protection of species of flora and fauna or natural phenomena of great scientific value. This zone includes the remaining mixed ombrophilous forest in various stages of succession (Fig. 3). Dystrophic Red Oxisols, Dystrophic Haplic Cambisols, and Dystrophic Red-Yellow Ultisols occur here, and slope values range from 0.17 to $87.04 \%$.

Zoning criteria: High environmental variability, species diversity, environmental susceptibility, and potential for awareness.

Administration Guidelines: The public is denied access to this zone. Scientific research activities are permitted if they are compatible with the conservation of the mixed ombrophilous forest, and act as a genetic bank for fauna and flora restocking. The collection of seeds and/or fruits aimed at zonal restoration are allowed only if the intensity of the collection is defined, and the dynamics of collected species are ensured. This zone is critical for preservation and acts as a scattering matrix of genetic material to recover protected areas. The main conflicts are related to predatory hunting and the presence of domestic animals.

Zone of Restricted Use: This zone covers an area of 453 ha, which corresponds to $12.5 \%$ of the total area of the Irati National Forest. The zone is intended to restore landscapes that are altered due to the cultivation of native species (Fig. 3). The remaining Araucaria angustifolia plantation, currently a dense understory, and the mixed ombrophilous forest, contributing to the beginningand medium-stage natural regeneration of the original matrix, are integral components of this zone. Dystrophic Red Oxisols and Dystrophic Haplic Cambisols occur here, and slope values range from 0.33 to $22.24 \%$.

Zoning criteria: Low to medium degree of vegetation conservation, environmental variability, richness or species diversity, environmental susceptibility, and potential for awareness.

Administration Guidelines: In this zone, research activities are allowed in order to ensure biodiversity recovery and environmental education studies. The collection of seeds and/or fruits aimed at habitat restoration, including in the surrounding areas, is also allowed if the intensity of collection is evidenced, thus ensuring the dynamics of collected species. Public visitation can only occur in the presence of a trained guide. Low or no human presence is expected, aside from predatory hunting and the presence of domestic animals.

Zone of Forest Management: This environmental zone covers an area of 859 ha, which corresponds to $23.7 \%$ of the total area of the Irati National Forest, and is occupied by Pinus spp and Eucalyptus spp cultivation (Fig. 3). The zone is intended for gradual landscape restoration due to the considerable evidence of human interference by predatory hunting and the presence of domestic animals. When the area is recovered/ or restored it should be inserted into the Conservation Zone. Dystrophic Red Oxisols, Dystrophic Haplic Cambisols, and Dystrophic Red-Yellow Ultisols 
occur in this zone. Slope values range from 0.61 to $45.94 \%$.

Zoning criteria: High degree of anthropogenic interference, low vegetation conservation, environmental variability, richness and/or species diversity, environmental susceptibility, and potential for awareness.

Administration Guidelines: The process of zone recovery must take place while removing exotic species and promoting natural restoration. The east region of this zone can be used for the sustainable production of native species, while the western region should be prioritized to exotic species removal as a strategy for joining the mixed ombrophilous forest fragments. Scientific research and environmental education activities aimed at restoring areas with biological contamination by exotic species will be permitted. The result of this contamination involves the loss of biodiversity, on which there is insufficient scientific information to support appropriate actions for environmental restoration, since they look for ecological recovery processes (Ziller and Galvão 2002). Access to the public will be allowed, so long as they are guided by trained professionals.

Zone of Public Use: This zone covers an area of 6.0 ha, corresponding to $0.2 \%$ of the total area of the Irati National Forest, comprising modified areas of mixed ombrophilous forest with beginning- to medium- stage regeneration by human activities (Fig. 3). The zone is equipped with infrastructure for recreation and environmental education such as the museum, interpretive trail, club, school, and local yerba mate processing (barbaquá). Dystrophic Red Oxisols occur in this zone, with slope values ranging from 1.60 to $12.08 \%$.

Zoning criteria: Low to medium evidence of vegetation conservation, environmental variability, richness and/or species diversity, and potential for environmental awareness.

Administration Guidelines: This area should be allocated for public visitation, recreation and environmental education with the use of the facilities of the museum, club, school and the interpretive trail. The club may be used for lectures, seminars, and scientific or educational events. Aiming to retrieve the history of the colonization period related to the production cycle of yerba mate, still considered an important regional economic resource, the "barbaquá" infrastructure facilities should be restored and activated, allowing an interactive factor with surrounding socio-cultural groups. The public will also be allowed to visit this area in order to demonstrate the steps involved in yerba mate handmade processing.

Zone of Special Use: Corresponding to $1.4 \%$ (52 ha) of the total area of the Irati National Forest. The zone is intended for maintenance services and administrative use, and includes administration and edifications in staff housing, a guesthouse, church, garage, nursery, workshop, vigilance home and internal access roads (Fig. 3). Dystrophic Red Oxisols, Dystrophic Haplic Cambisols, and Dystrophic Red-Yellow Ultisols occur in this zone, and slope values range from 0.14 to $25.55 \%$.

Zoning criteria: Low evidence of vegetation conservation, environmental variability, low richness and/or species diversity, and high potential for environmental awareness.

Administration Guidelines: Besides the administrative activities aimed at the maintenance of service facilities and roads, the restoration of staff residences should be encouraged. Groups of visitors can use the unoccupied housing, which can also act as shelter for researchers.

Zone of Conflicting Use: This zone covers an area of 35 ha, corresponding to $1.0 \%$ of the total area of the Irati National Forest: herbaceous vegetation predominates. This area is occupied by Irati-Sabará and Areia-Ponta Grossa PTLs, operated by COPEL and ELETROSUL corporations, respectively. The presence of these PTLs is incompatible with established targets of the management plan (Fig. 3). Dystrophic Red Oxisols and Dystrophic Haplic Cambisols occur in this zone, and slope values range from 0.10 to $22.24 \%$.

Administration Guidelines: The Irati-Sabará PTL crosses the Intangible, Restricted Use, Forest Management, and Conservation Zones. Due to its low operating voltage $(138 \mathrm{kV})$ and the height of the cable from the ground, this area can be used for cultivating herbaceous and shrub species for seedling production and restoration of the area, since it respects the maximum height $(2.5 \mathrm{~m})$ for crops (ABNT 1985). The Areia-Ponta Grossa PTL, due to its higher operating voltage $(230 \mathrm{kV})$ and lower cable height from the ground, and as it crosses the Intangible Zone, should remain with minimal intervention, ensuring the safety limits 
regarding the maximum height for vegetation (ABNT 1985).

Since the PTLs cross different habitats with low richness and/or species diversity, they should be adjusted by COPEL and ELECTROSUL corporations to environmentally compensate for the occupation of the servitude area. Alternatively, these corporations could adopt the current legislation (BRASIL 2000), collaborating in the design and implementation of the management plan.

Buffer Zone: This zone represents a strategy to minimize negative and maximize positive effects of land use in the surrounding area. The Buffer Zone is referred to as a peripheral area of a conservation unit, where use restrictions or special measures for additional protection are defined, while providing benefits to neighboring socio-communities (Brandon 1997). The efficient use of buffer zones has been endorsed by environmentalists and management agencies of protected areas (Prins and Wind 1993).

The Buffer Zone in the current study $(1 \mathrm{~km})$ covers an area of 4,603 ha (Fig. 3), including six types of land and cover uses, clustered into two main classes: natural and anthropic. The natural class is the most representative, covering $77.9 \%$ of the zone (3,588.4 ha), characterized by forest components (grass capoeira (885.9 ha), native forest $(2,049.4$ ha) and wetland (653.1 ha). The anthropic class occupies $22.1 \%$ of the zone $(1,015 \mathrm{ha})$ with the predominance of forestry (708.6 ha), followed by agriculture (210.9 ha), and bare soil (95.5 ha).

These results are quite different from those reported in other studies, which show a prevalence in terms of anthropic use (Scariot et al. 2015). The natural land uses (grass capoeira, native forest, and wetland) make up a perimeter extension with the same use restrictions in place for the Irati National Forest. The anthropic land uses (agriculture, forestry, and bare soil) comprise a perimeter that should include uses that enable the integration of socio-communities into the Irati National Forest.

Part of the natural vegetation of the buffer zone is used as Faxinais, defined as traditional, small-scale silvopastoral systems that combine the conservation of the remaining forest with animal subsistence production. In the region, there is a predominance of small family farms. Larger, nonfamily farms are less frequent. Other anthropogenic uses, such as agriculture, forestry, and urban areas, represent $22 \%$ of the buffer zone. The spatial distribution of land and cover uses highlights the need for strategies for the conservation of natural vegetation, thus ensuring potential scenarios for biodiversity conservation.

The implementation of legislation to define a buffer zone of $10 \mathrm{~km}$ is not appropriate in this case, as it includes urban areas of surrounding municipalities (Fernandes Pinheiro: $2.45 \mathrm{~km}$; Teixeira Soares: $4.36 \mathrm{~km}$; Irati: $5.90 \mathrm{~km}$; Imbituva: $8.58 \mathrm{~km}$ ). Act No. 13/90 (BRASIL 1990) considers a $10 \mathrm{~km}$ radius around a protected area as the extension limit where any activity that can compromise biodiversity should be licensed. However, there are no specific guidelines for planning buffer zones (Martino 2001).

Administration Guidelines: The establishment of the buffer zone should be preceded by an engagement with surrounding socio-communities searching to raise awareness regarding the ecological and social importance of the Irati National Forest. Different mitigation measures may be adopted to minimize possible actions that may jeopardize the local biodiversity. The establishment of the agroforestry system in the immediate surroundings with an herbaceous and shrubby extract of multipurpose native species for the production of fruits, seeds, wood, medicinal plants, and yerba mate may be considered for adoption. Another alternative would be the incentive for the agroecological production of crops used traditionally by farmers in the region such as corn and beans. Environmental education activities should also be encouraged with the surrounding socio-communities.

\section{CONCLUSIONS}

The mixed ombrophilous forest has an economic, social, cultural and environmental significance for the southern region of Brazil. In the last century, the forest was considered of great importance for regional development, especially as a source of wood and yerba mate, supplying the national and international markets. Even today, the native plants of this phytophisiognomy are an important use option by family farmers and traditional communities, and in obtaining raw materials for agricultural, food, pharmaceutical and other industries (Caffer 2005).

However, for most non-timber forest production chains, there are no reports of plantations or sustainably managed mixed ombrophilous forests; 
therefore, production chains are based almost exclusively on extraction by social communities, which provides a means of obtaining additional income for many communities. However, the economic pressure allowed via a predatory extraction process results in a significant reduction in natural populations of harvested species, many of which are currently included on the endangered species list (Reis et al. 2000).

In recent years, Brazilian environmental legislation has created possibilities for biodiversity management, with interventions in legally protected areas, especially on small farms and in the case of social interest or low environmental impact. These tools also enable the sustainable management of agroforestry without prejudice to the native vegetation. The ecological function of the legally protected area (BRASIL 2001; BRASIL 2006a; BRASIL 2006b) provides technical criteria ensuring the sustainable use and conservation genetics of these native populations.

As a legally protected area of federal significance, the Irati National Forest contributes greatly to local and regional biodiversity, ensuring the environmental quality of the hydrographic basins of the Antas and Imbituva Rivers. Regarding the regional landscape, the Irati National Forest interacts with Fernandes Pinheiro Ecological Station and the Biological Reserve of Araucaria, connecting natural vegetation patches of fundamental importance for biodiversity conservation. The connectivity between natural habitats from northern and southern regions of Irati National Forest can be showcased as a natural corridor of native forest and wetland areas. This integration between natural habitats enables the genetic flow between species of regional biota, mainly associated with the hydrographic basins of the Imbituva and Antas Rivers, which is strategically important for the conservation of the mixed ombrophilous forest. The presence of exotic species within the Irati National Forest may result in risks to the remaining mixed ombrophilous forests. Therefore, it is critically urgent to remove exotic species and promote the subsequent recovery of the area. These actions are vital when considering the percentage of remaining mixed ombrophilous forest at different successional stages in Paraná state, which will be subjected to persistent deforestation activities.

This environmental zoning proposal will create a wide dialogue between environmental government agencies, surrounding socio-communities, the productive sector, and organized civil society in view of the implementation of the management plan and biodiversity conservation of the Irati National Forest.

The environmental zone and management plan for the Irati National Forest are critical for the effectiveness of efforts that integrate ecosystem conservation and community development. This disagreement between conservation and community development stems from the different values and expectations people place on this integration; while some prioritize ecosystem viability and use development as a means to enhance conservation, others prioritize community viability and consider conservation a means to an end. The absence of an environmental zone theoretical framework for the Irati National Forest and community viability has contributed to the current disagreement, making it difficult to design, monitor, and evaluate integrated projects. The environmental zone theoretical framework proposal shows that ecosystem conservation and community survival are interdependent and should be given equal emphasis if both are to benefit. By outlining specific factors that enhance ecosystem and community viability, this framework can aid in the design and evaluation of the management plan of the Irati National Forest.

\section{ACKNOWLEDGEMENTS}

The authors would like to thank the financial support of CNPq - CTHIDRO: Proc: 140971/20025. $\mathrm{CNPq}$

Proc. 470768/2012-6.

\section{REFERENCES}

Achard F, Eva HD, Stibig HJ, Mayaux P, Gallego J, Richards T, Malingreau JP. Determination of deforestation rates of the world's humid tropical forests. Science. 2002; 297: 999-1002.

ABNT. Projeto de linhas aéreas de transmissão de energia elétrica. NBR 5422. Associação Brasileira de Normas Técnicas. 1985: 22p.

Brandon K. Policy and practical considerations in landuse strategies for biodiversity conservation. In: R.A. Kramer, C. van Schaik, J. Johnson (Eds.). Last stand: Protected areas and the defense of tropical biodiversity. New York: Oxford University Press. 1997: 90-114.

BRASIL. Resolução N ${ }^{\circ} 13 / 90$ do CONAMA. Institui normas referentes ao entorno das Unidades de Conservação visando a proteção dos ecossistemas existentes. 1990. 
BRASIL. Lei $\mathrm{n}^{\circ}$ 9985, 18 de Julho de 2000. Institui o Sistema Nacional de Unidades de Conservação SNUC. 2000. (www.mma.gov.br).

BRASIL. Medida Provisória $\mathrm{n}^{\circ}$ 2.166-67, de 24 de Agosto de 2001. Altera os arts. $1^{\circ}, 4^{\circ}, 14,16$ e 44, e acresce dispositivos à Lei $\mathrm{n}^{\circ} 4.771$, de 15 de Setembro de 1965, que institui o Código Florestal, bem como altera o art. 10 da Lei ${ }^{\circ}$ 9.393, de 19 de dezembro de 1996, que dispõe sobre o Imposto sobre a Propriedade Territorial Rural - ITR, e dá outras providências. 2001. BRASIL. Decreto no 4340 de 22 de Agosto de 2002. Institui a regulamentação da Lei do SNUC. 2002. (www.mma.gov.br).

BRASIL. RESOLUÇÃO CONAMA n 369, de 28 de Março de 2006: Em atendimento à Lei 4.771, de 15 de setembro de 1965, altera pela MP 2.166/2001. Dispõe sobre os casos excepcionais, de utilidade pública, interesse social ou baixo impacto ambiental, que possibilitam a intervenção ou supressão de vegetação em Área de Preservação Permanente-APP. 2006a.

BRASIL. Lei N ${ }^{\circ} 11.428,22$ de Dezembro de 2006. Dispõe sobre a utilização e proteção da vegetação nativa do Bioma Mata Atlântica, e dá outras providências. 2006b.

Caffer MM. Caracterização do conhecimento de populações locais sobre a diversidade de recursos genéticos vegetais em remanescentes de floresta ombrófila mista. Dissertação (Mestrado em RGV) Universidade Federal de Santa Catarina, Florianópolis. 2005.

Castella PR, Britez RM. A floresta com Araucária no Paraná: Conservação e diagnóstico dos remanescentes florestais. Fundação de Pesquisas Florestais do Paraná. PROBIO, Ministério do Meio Ambiente. 2004: 236p.

Caviglione, JH, Kiihl, LRB, Caramori, PH, Oliveira, D. Cartas climáticas do Paraná. Londrina: IAPAR, 2000. CD

Chapin FS III, Zavaleta ES, Eviner VT, Naylor RL, Vitousek PM, Reynolds HL, et al. Consequences of changing biodiversity. Nature. 2000; 405: 234-242.

Costa MH, Yanagi SNM, Souza PJOP, Ribeiro A, Rocha EJP. Climate change in Amazônia caused by soybean cropland expansion, as compared to caused by pastureland expansion. Geophysical Research Letters. 2007; 34: 1-4.

EMBRAPA. Centro Nacional de Pesquisa de Solo (Rio de Janeiro, RJ). Sistema de Avaliação da Aptidão Agrícola das Terras. A. Ramalho Filho, K. J. Beek (Eds.). 3rd ed. Rio de Janeiro: Embrapa Solos. 1995: $65 \mathrm{p}$.

FUPEF. Fundação de Pesquisas Florestais do Paraná. Carta Florestal da Floresta Nacional de Irati. 1986.

Gubert FA. Levantamento de áreas de relevante interesse ecológico (ARIE) no Paraná. In: Congresso Florestal do Paraná, 2. Anais. Curitiba. 1988; 1: 136-160.

Helmut JG, Lambin EF. Proximate causes and underlying driving forces of tropical deforestation. BioScience. 2002; 52: 143-150.
Hohnwald S, Rischkowsky B, Camarão AP, SchultzeKraft R, Rodrigues Filho JA, King JM. Integrating cattle into the slash-and-burn cycle on smallholdings in the Eastern Amazon, using grass-capoeira or grasslegume pastures. Agriculture, Ecosystems and Environment. 2006; 117: 266-276.

Howard WC, Tompson K. The conservation and management of African wetland. In: P. Denny (Ed.). The ecology and management of Africa wetland vegetation. Boston: Wolfgang Junk Publ. Geobotany. 1985, 6p.

IBAMA. Roteiro Medológico para elaboração de plano de manejo para florestas nacionais. Brasília: IBAMA, MMA. 2003: 56p.

IBGE. Manuais técnicos em geociências número 7 . Manual técnico de uso da terra. 3rd ed. Rio de Janeiro, RJ, Brasil: IBGE. 2013.

IDS. Indicators of sustainable development: Brazil. Coordination of natural resources and environmental studies. Rio de Janeiro: IBGE. 2015.

Kareiva P, Watts S, McDonald R, Boucher $\mathrm{T}$. Domesticated nature: Shaping landscapes and ecosystems for human welfare. Science. 2007; 316: 1866-1869.

Lambin EF, Meyfroidt P. Global land use change, economic globalization, and the looming land scarcity. PNAS. 2011; 108(9): 3465-3472.

Laurance WF, Sayer J, Cassman KG. Agricultural expansion and its impacts on tropical nature. Trends in Ecology \& Evolution. 2014; 29(2): 107-116.

Martino D. Buffer zones around protected areas: A brief literature review. Eletronic Green Journal. 2001. http://www.escholarship.org/uc/item/02n4v17n/ (acesso em Dezembro de 2009).

Matson PA, Parton WJ, Power AG, Swift MJ. Agricultural intensification and ecosystem properties. Science. 1997; 277: 504-509.

Mazza CAS, Mazza MCM, Santos JE. Caracterização ambiental da paisagem da Microrregião Colonial de Irati, PR. In: J.E. Santos, F. Cavalheiro, J.S.R. Pires, C. Henke-Oliveira, A.M.Z.C.R Pires (Eds.). Faces da polissemia da paisagem: Ecologia, planejamento e percepção. São Carlos: Editora RiMa. 2005: 409-424.

Millennium Ecosystem Assessment. Living beyond our means: Natural assets and human well being. 2006. http://www.millenniumassessment.org/ (accessed in December 2014).

MINEROPAR. Atlas Geológico do Paraná. Minerais do Paraná MINEROPAR. Fundação Araucaria. Curitiba. 2001, 116p.

Prins H, Wind J. Research for nature conservation in south-east Asia. Biological Conservation. 1993; 63: 43-46.

PROBIO. Projeto de Conservação e Utilização Sustentável da Diversidade Biológica Brasileira. Subprojeto conservação do bioma Floresta com Araucária: Relatório Final. Curitiba: FUPEF,. 2v. 2001 (CD). 
Reis MS, Mariot A, Di Stasi LC. Manejo de populações naturais de plantas medicinais na Floresta Atlântica. In: A.C. Diegues, V.M. Viana (Eds.). Comunidades tradicionais e manejo dos recursos naturais da Mata Atlântica. São Paulo: USP, ESALQ. 2000: 95-102.

Scariot EC, Almeida D, Santos JE. Connectivity dynamics of Araucaria forest and grassland surrounding Passo Fundo National Forest, southern Brazil. Natureza \& Conservação. 2015; 13: 54-59.

United Nations. Global status of biological diversity: Report of the Secretary-General. Commission on Sustainable Development acting as the preparatory committee for the World Summit on Sustainable Development. United Nations. 2001, 7p.
USGS. United State Geological Survey. 2005. http://edc.usgs.gov/ (accessed in December 2014).

Veloso HP, Goes-Filho L. Fitogeografia Brasileira, classificação fisionomico-ecológica da vegetação neotropical. Salvador, Bahia: Ministério das Minas e Energia-Projeto RADAMBRASIL. 1982, 80p.

Ziller SR, Galvão F. A degradação da estepe gramíniolenhosa no Paraná por contaminação biológica de Pinus elliottii e Pinus taeda. Floresta. 2002; 32: 41-47. Wandelli EV, Fearnside PM. Secondary vegetation in central Amazonia: Land-use history effects on aboveground biomass. Forest Ecology and Management. 2015; 347: 140-148. 